\title{
A Philosophical Solution to the Problem of Socrates
}

George Rudebusch

Chris Turner

Abstract Socrates' purposes, in his philosophical conversations with others, remain a puzzle. We review eleven distinct interpretive options, many of which stretch back more than a hundred years, finding all of them untenable. We then propose an original, twelfth interpretation as the most faithful and charitable alternative. Our discussion takes as its focus Plato's dialogue Laches as a representative of the aporetic dialogues.

\section{Introduction}

How to interpret Socrates' purpose in his philosophical conversations with others has remained a puzzling question that has persisted to this day, with a variety of approaches on offer, none of which has achieved consensus, though some hold more currency than others. In what follows, we investigate eleven distinct interpretive options, many of which stretch back more than a hundred years. We critique these interpretations, making clear that whatever insight and value they may have for a reading of Socrates and Plato, they are ultimately untenable. We then offer a novel, twelfth interpretation as the only plausible alternative. ${ }^{1}$

In the course of analysis we have chosen to focus on Plato's dialogue Laches because it serves perfectly as a test case for reading a Socratic dialogue, and most of the issues raised here can be extrapolated from the present, more narrow, focus to a wider scope that includes without question all the aporetic dialogues and perhaps every dialogue in which Socrates is the principal figure. We aim to show that in interpreting Socrates one need not impose hidden meanings, esoteric clues, implicit messages, anachronistic ideologies or subversive intentions upon the Platonic dialogues in order to unlock their 'true' meaning but rather should note Socrates' own explicit words and

\footnotetext{
${ }^{1}$ Our interpretation has been anticipated only by Rudebusch, Socrates (Malden, MA: WileyBlackwell, 2009) but that proposal, in a book aimed at non-specialists, did not make a comparative assessment of the alternative interpretations.
} 
intentions as Plato has presented them to us and trace them at work in his own practice in conversation with others. The figure of Socrates that emerges accords with his own self-presentation within the Platonic dialogues and with his avowed intention to save himself and others through a lived practice of cross-examining the claims to knowledge of purported 'experts'. As should become clear, this concerns much more than simply refuting the vain pretensions of the conceited and powerful; it has to do rather with saving ourselves and others from the unwitting guilt that characterizes our condition of ignorance, a guilt that if not checked threatens to destroy us, our loved ones, and our communities, despite our best intentions and loftiest hopes.

The Laches is a dialogue about courage. Two fathers, Lysimachus and Melisias, approach two Athenian generals, Laches and Nicias, for advice: should they enroll their sons in a fancy martial arts class? The two generals give conflicting advice, and the fathers turn to Socrates to cast the 'deciding vote'. Though Socrates is the junior member of the group, Laches has seen him display conspicuous courage in battle, and Nicias has heard good advice from Socrates in finding a teacher for his own son. They agree to grant their junior the privilege of speaking freely among them.

But Socrates is reluctant to advise. Instead, he proposes that the would-be advisers demonstrate their mastery of the subject - how to raise excellent sons - by giving an account of the part of human excellence that is in question, namely, courage. Laches goes first, defining courage as standing one's ground, then as endurance of the soul and finally as wise endurance of the soul. Socrates finds counter-examples to the first definition, giving examples of courage in flight. And Laches is quick to admit that foolish endurance cannot be a human excellence. Finally, Laches is perplexed when Socrates proceeds to give numerous examples of wise endurance that are not courage, and of foolish endurance that are courage.

At this point, Nicias enters with his proposal. Instead of wise endurance he proposes wisdom alone as definition. And, unlike Laches, he is able to identify the specific wisdom that is courage, namely knowledge of what is fearful (i.e. future evils) and what is hopeful (future goods). However, Socrates, after eliciting a few undeniable premises, shows that such a definition would make courage the same as the whole of virtue - yet all have agreed that courage is merely one virtue among others, such as reverence, soundness of mind, and righteousness. Thus Nicias, too, is perplexed, which leads to Socrates' concluding advice that all must go back to school. Had Laches and Nicias heeded Socrates' advice they might not have met with catastrophic defeat on 
their military campaigns in the decade that followed. The manner in which they lost, the bad decisions they made at crucial moments, is foreshadowed with dramatic irony by Plato in the dialogue. ${ }^{2}$ We are meant to notice that turning away from and not taking up the philosophical life Socrates shares with us leaves us open, in our ignorance, to making colossal blunders, in which despite our intentions we are responsible for our own destruction. Indeed in cases like the one under discussion, nothing less than the survival of one's own community is at stake.

Taken at face value, the dialogue, after a lengthy dramatic prelude, is an investigation into ethical theory, searching for a definition of a human virtue. In what follows, we call this the Ethical Theory Interpretation. In modern times, this interpretation originated in Germany in the 1800s. Such an interpretation sees the dialogue's final perplexity as inviting a solution by the reader. The Ethical Theory Interpretation remains the standard interpretation, outside of Germany, to the present day, although none of the alternatives within it has gained dominance. But there are at least nine additional alternatives to the Ethical Theory Interpretation as a whole, nearly all of which were first proposed in Germany, and each of which we will consider in turn.

Paul Natorp proposed what we call a Theory of Knowledge Interpretation: the search in the dialogues is not for an account of virtue but for an account of knowledge itself. ${ }^{3}$ Where we seem to have the former it is only ever in service to and aiming at the latter. In view of the impossibility of reaching a resolution to the competing ethical theories, Max Hiestand proposed a Fruitlessness Interpretation. ${ }^{4}$ The final perplexity is not an invitation to the reader to provide a definition of courage, but a sign of the impossibility of knowledge of virtue. One might think here of Clitophon's lament (at 408d-e) and the influence of Socrates upon ancient Skepticism. George Grote provided

${ }^{2}$ A comparison of the generals' respective deaths, as depicted by Thucydides, with certain features of their definitions in the dialogue (namely, the claim that the man who in battle endures wisely holding a superior position is less courageous than his opponent, at 193a, for Laches; the claim that it is not proper for the general to take orders from the seer, at 198e, for Nicias) illuminates the connection Plato would like to draw between an interlocutor's refusal to take their ignorance seriously, to take up the philosophical life and grapple with one's ignorance, and the destructive consequences of continuing to act as though one knew what one was doing.

${ }^{3}$ Paul Natorp, Platos Ideenlehre: Eine Einführung in den Idealismus (Leipzig: F. Meiner, 1903).

${ }^{4}$ M. Hiestand, Das sokratische Nichtwissen in Platons ersten Dialogen (Zürich: 1923). 
yet another interpretation of the negative ending of Socratic dialogues: the goal is the creation and furtherance of individual, self-thinking minds, which we consider as a version of the Fruitlessness Interpretation and call the Think for Yourself Alternative, tracing it back to Hegel. ${ }^{5}$ We next consider several interpretations that view the central concerns of the dialogues as non-theoretical or praxis-oriented. As an alternative to all interpretations seeking (or skeptically denying) a theoretical solution to the final perplexity, Paul Friedländer 1928 proposed an Ineffable Knowledge Interpretation: the dialogue is not searching for a theory but showing us a non-theoretical know-how, in the character of Socrates, who exemplifies everyday civic virtue. ${ }^{6}$ On this account the perplexity in which the dialogue ends is his method of training students. Kurt Hildebrandt proposed a more radical non-theoretical alternative, a Will to Power Interpretation: Socrates aims in the dialogues to identify and inspire a master class who in great deeds of self-assertion will create and lead a new society. ${ }^{7}$ As with the Think for Yourself Interpretation such a view anachronistically imposes a contemporary ideology upon its ancient text, though unlike in the former case here Socrates is perversely given an intention more fitting for his sophistical arch-enemies, Callicles and Thrasymachus. More plausibly, Pierre Hadot and Michel Foucault view the figure of Socrates in the dialogues as a model for the philosophical way of life with which Plato aims to inspire us, while Francisco J. Gonzalez views him as displaying a courageous form of knowing ignorance. ${ }^{8}$ After the Second World War, Hans Krämer, ${ }^{9}$ Konrad Gaiser, ${ }^{10}$ and Michael Erler ${ }^{11}$ proposed interpretations of the Laches based upon Plato's Unwritten Doctrines.

${ }^{5}$ G. Grote, Plato and the other companions of Sokrates, vol. 1 (London: John Murray, 1865). Page references to $2^{\text {nd }}$ edition, London, 1885. G.W.F. Hegel, Vorlesungen über die philosophie der Geschichte, $3^{\text {rd }}$ edition (Berlin: Duncker und Humblot, 1848).

${ }^{6}$ P. Friedländer, Platon, vol. 1 (Berlin: Walter de Gruyter \& Co., 1928). Page references to $3^{\text {rd }}$ edition, Berlin, 1964.

${ }^{7}$ K. Hildebrandt, Platon: Der Kampf des Geistes um die Macht (Berlin: G. Bondi, 1933).

${ }^{8}$ P. Hadot, Philosophy as a Way of Life: Spiritual Exercises from Socrates to Foucault (Malden, MA: Blackwell, 1995). M. Foucault, The Courage of Truth: The Government of Self and Others II. Lectures at the Collège de France, 1983-1984 (New York: Picador, 2012). F. J. Gonzalez, Dialectic and Dialogue: Plato's Practice of Philosophical Inquiry (Evanston: Northwestern University Press, 1998).

${ }^{9}$ H. J. Krämer, Arete bei Platon und Aristoteles. Zum Wesen und zur Geschichte der platonischen Ontologie (Heidelberg: 1959).

${ }^{10}$ K. Gaiser, Protreptik und Paränese bei Platon. Untersuchungen zur Form des platonischen Dialogs (Stuttgart: Kohlhammer, 1959).

${ }^{11}$ M. Erler, Der Sinn der Aporien in den Dialogen Platons (Berlin: de Gruyter, 1987). 
These are a small set of metaphysical principles — about posits such as the One, the Many, the Bound, and the Boundless - that can be reconstructed from reports of Aristotle and others. According to this school of interpretation, Plato wrote the Laches to attract talented students to his academy, putting hints in it to remind insiders of his oral teachings. According to this interpretive alternative, Socrates is a metaphysician leading students to Platonic Forms.

\section{Ethical Theory Interpretations}

Ethical theory interpretations agree in supposing that Socrates aims to develop an ethical theory in his conversation with Laches and Nicias. Some see Socrates as aiming to teach an ethical theory, in which case he already has one that he wishes to impart, while others see Socrates as aiming to search for an ethical theory, in which case he enlists the two generals, supposed experts in the matter at hand, in the hopes of discovering the nature of courage. In either case, all such interpretations agree that Plato, in writing the dialogue, has given us a theory of courage in the dialogue. The theory is implicit because, of course, the dialogue explicitly ends in perplexity.

Unfortunately, proponents have reached no consensus, nor even established a dominant account, of what the ethical theory is. At the beginning of modern interpretation of Platonic dialogues, within a decade of each other, German scholars presented two alternatives. Karl Steinhart proposed to define courage as a combination of the insights of Laches and Nicias: the part of virtue that is a kind of endurance of soul combined with knowledge of what is good and bad for human beings. ${ }^{12}$ We will refer to this as the Wise Endurance Alternative. Franz Susemihl, ${ }^{13}$ in contrast, proposed that courage is not a mere part but the whole of virtue, so that the words courage, soundness of mind, righteousness, reverence, and wisdom all refer to one and the same thing, namely knowledge of what is good and bad for human beings. We will call this the Knowledge Alone Alternative.

Socrates refutes each of the definitions that Laches and Nicias propose. These definitions, taken one by one, are each deficient. Yet, according to the Wise Endurance Alternative, the dialogue is artfully constructed so that the reader is able to construct the

\footnotetext{
${ }^{12}$ K. Steinhart, Platons saemmtliche Werke, vol. 1 (Leipzig: 1850).

${ }^{13}$ F. Susemihl, Die genetische Entwickelung der Platonischen Philosophie Part 1 (Leipzig: B.G. Tuebner, 1855).
} 
full and true definition of courage by combining the individual elements proposed within the dialogue, in particular those elements of his interlocutors' definitions that Socrates does appear to endorse, even if he refutes their arguments as wholes. As Steinhart (1850: 354) puts it, "all aspects of the concept they seek are explicitly stated in the course of the investigation, just as it stands, and [Plato] believed he could leave for the reader [to supply] only the last word of the analysis that sums it all up (das letzte Wort der zusammenfassenden Betrachtung)."

Steinhart distinguishes three elements. Laches provides the non-cognitive element, endurance of the soul. Nicias provides the cognitive element, knowledge of what is to be dreaded and dared - that is, future good and bad things. Socrates finally extends the object of that knowledge to what is good and bad without reference to time. The definition assembled from these three elements makes courage a proper part of virtue as a whole. This result validates the part/whole thesis about the relation of courage to virtue, a thesis affirmed at the beginning of the examination of Laches and again at the beginning of the examination of Nicias. Courage on this account is, like all virtue, a kind of knowledge, but is distinctive in both the futural tendency of its cognition, that is, its 'immediate object', and in its non-cognitive component or 'form', endurance. Extrapolating from this, one might speculate that the other parts of virtue could then presumably be distinguished by either the temporal tendency of their cognition or their specific non-cognitive components. Thus Steinhart (1850: 354): "Courage is different from [the other] virtues both in its immediate object and in its form. For its nearest object is either a future good for us, that we attain by courageous battle, or a future evil that we wish to avoid through steadfast endurance [ . . . In form, moreover, courage shows itself as sound-minded steadfastness (besonnene Standhaftigkeit), as unwavering persistence at that which reason has recognized as good and right." Bonitz (1886: 215) and Von Arnim (1914: 26-29) also endorse this position. ${ }^{14}$

The Wise Endurance Alternative of the Ethical Theory Interpretation finds defenders to the present day. For illustration, we will next consider merely two such proponents, Darrell Dobbs and Aristide Tessitore. ${ }^{15}$ Dobbs claims that, "The dialogue as

${ }^{14}$ H. Bonitz, Platonische Studien (Berlin: 1886), $3^{\text {rd }}$ edition. Hans von Arnim, Platos Jugenddialoge und die Entstehungszeit des Phaidros (Leipzig: B.G. Tuebner, 1914).

${ }^{15}$ D. Dobbs, "For Lack of Wisdom: Courage and Inquiry in Plato's Laches", in Journal of Politics 48 (1986), 825-850. A. Tessitore, "Courage and Comedy in Plato's Laches", in The Journal of Politics 56 (1994), 115-133. Similar proponents are Robert Hoerber, "Plato's Laches", in: Classical Philology 63 (1968), 95-105; Erazim Kohak, “The Road to Wisdom”, in 
a whole...reveals courage itself as a firmness or perseverance resisting the terrors of the unknown" (1986: 826). Laches has this courage, Dobbs maintains, while Nicias displays for us how the desire for certainty precludes courage by paralyzing our judgment (1986: 848). In the first place, Dobbs does not explain how Socrates' endorsement of Nicias' claim, which is in fact the former's own, that "every man is good in that wherein he is wise, and bad in that wherein he is unlearned" (194d) would not also be open to his objection. Next, Dobbs seems to have misrepresented the episteme that Nicias speaks of. Is Nicias' proposed knowledge really a scientific expertise or might it not instead be similar to a practical or professional knowledge, the highest form attainable in a given time, grounds for belief and action but not certainty? One might also note that, at least to some extent, the fear of the unknown might be said to spur the advancement of useful knowledge. To persist in ignorance is no virtue.

The contrast between the two principal interlocutors is meant to illustrate two conflicting ways of dealing with uncertainty. Dobbs holds Laches up as an example of courage for acknowledging his aporia, while faulting Nicias for not admitting aporia since he is afraid of the unknown (1986: 848). Yet Laches does not, properly speaking, acknowledge his aporia. While Laches does admit that he is perplexed, he claims his perplexity to result from the fact that he cannot rightly say what he is already sure he knows. If Laches acknowledged his aporia, he would admit that he does not know what courage is. Instead, he blames his inability to speak his thoughts well enough. Surely, we are meant to remember here Laches' earlier remarks on being both a lover and a hater of speech, as his own excuse entails that, since his words are out of tune with his deeds, he must be despicable in his own eyes. He suffers a form of poetic justice at his own hands and with the help of Socrates.

Tessitore 1994 suggests that the discussions with Laches and Nicias reveal Socrates as an example of the courage sought in the dialogue (122). Socrates has the kind of battlefield endurance Laches recommends, and the skill in argument and seeking of knowledge that Nicias values. Socrates is the hero of the dialogue who provides a model of the harmony of word and deed that Laches praises at the outset of their search

Classical Journal 56 (1960), 123-132; Michael O'Brien, “The Unity of the Laches”, in Essays in Ancient Greek Philosophy. Ed. by J. P. Anton and G. L. Kustas (Albany: SUNY Press, 1971), 303-315; and Daniel Devereux in both "Courage and Wisdom in Plato's Laches", in Journal of the History of Philosophy 15 (1977), 129-141, and "The Unity of the Virtues in Plato's Protagoras and Laches", in The Philosophical Review 101 (1992), 765-789. 
for a suitable definition of courage. ${ }^{16}$ There are two objections to this: on the one hand, a single example, tinged with the contingent and particular features of its situation, is hardly a sound basis for an ethical theory, and on the other hand, Laches praised those speakers whose words accord with their deeds. Socrates for all his merits claims to be just as perplexed as the others and has shared in their failure to properly define courage. Like Laches and Nicias, he may have acted bravely in the past and may even display a kind of courage in deed during the conversation (as at 194a), but also like them he is not able to harmonize his words with such deeds. His explicit acknowledgement of his own shortcomings and suggestion that all, including him, seek a teacher, argues against our attributing to him the virtue of courage.

The Knowledge Alone Alternative agrees with the Wise Endurance Alternative in seeing Socrates as aiming to develop an ethical theory in the course of the dialogue. It also agrees with Steinhart's reading, cited above, that every aspect of the concept to be defined, courage, is stated at some point in the course of the dialogue, and all we as readers need to do is put it together. It disagrees in that it finds a different virtue theory. Instead of finding a definition of courage as wise endurance, it finds courage defined as knowledge of what is good and bad for human beings, all things considered.

Thus Susemihl (1855: 35) asked "whether [...] the point of the dialogue, through an analysis of the concept of courage, is to reduce it to the concept of virtue in general $[\ldots]$ thus in general to present the differences between the particular virtues as inessential and especially to refute the usual notion of distinct virtues existing side by side (getrennt neben einander bestehenden Tugenden)." He answers the question in the affirmative a few pages later (likewise his 1855: 39 and Eduard Zeller [1859: $376 \mathrm{n}$. $3]^{17}$ ). Interpreters continue to defend the Knowledge Alone Alternative to the present day. ${ }^{18}$

${ }^{16}$ Similar proponents are Chris Emlyn-Jones, "Dramatic Structure and Cultural Context in Plato's Laches", in Classical Quarterly 49 (1999): 129 and Richard Foley, "The Better Part of Valor: The Role of Wisdom in Plato's Laches, in History of Philosophy Quarterly 26 (2009): 229-230.

${ }^{17}$ E. Zeller, Die Philosophie der Griechen volume II part 1, $2^{\text {nd }}$ edition (Tübingen: 1859).

${ }^{18}$ After Santas (in "The Socratic Paradoxes". Philosophical Review 73 [1964]:147-64. Revised version in Santas 1979) defended the philosophical viability of the Knowledge Alone Alternative, Gregory Vlastos (in "The Unity of Virtues in the Protagoras." Review of Metaphysics 25 [1972], 415-458. Reprinted in Vlastos 1981) interpreted Socrates as reducing virtue to many branches of knowledge, while Terry Penner (in "The Unity of Virtue". Philosophical Review 82 [1973], 35-68. Reprinted in Benson 1992) to only one. See Rudebusch, "Socrates, Wisdom, and Pedagogy," Socratic, Platonic and Aristotelian Studies: Essays in 
As Bettina Fröhlich (2007:128) points out, the inconclusive dispute between the two alternative ethical theory interpretations is evidence that "both positions are in the end problematic." 19 And if they are problematic, which the scholarly impasse suggests, this is already reason to view with suspicion the notion that Plato intended readers to simply put what was right in the definitions together and make explicit what he purposefully left implicit. We would not expect someone as intelligent and gifted a writer as Plato, if he intended to impart an ethical theory, to have left a gap between the implicit and explicit in the dialogue that centuries of scholarship has been unable to close.

The great advantage of the Wise Endurance Alternative is that it is able to accept at face value Socrates' suggestion — indeed agreement — t hat courage is a proper part of virtue. This alternative distinguishes courage from the other virtues by means of the requirement that the non-cognitive character trait of endurance-in addition to appropriate cognition or knowledge - be part of the definition of courage. Yet such a requirement is the Achilles heel of this alternative. For the courage that is a human excellence is no more enduring in its nature than it is yielding.

As Socrates points out to Laches, in some cavalry and chariot fighting men who do not stay in place and do run away while fighting are also brave (191a-b). Even if we restrict ourselves to the case of the fighting of armored foot soldiers, men who yield can be as brave as men who endure, as the Spartans famously were at Plataea. "They say that the Spartans, up against troops with wicker shields, chose not to stand and fight them but to run away - and when the Persians broke ranks to pursue them, they turned upon them like cavalry and by fighting this way won the battle" (191b8-c5). The field of rescue work is another illustration that courage is no more enduring than yielding. The courageous rescuer - for example, a shepherd searching for a lost sheep — will endure in searching only so far as it is wise so to act. At some point, the risk to the rest of the flock or to the shepherd herself will require yielding to necessity, not enduring in the rescue. The bivalence of the non-cognitive trait of endurance is of course not restricted to the areas of infantry and rescue work, but generalizes to all spheres of human conduct, even academic scholarship. It often requires more courage of a scholar to abandon a position than to persist in its defense.

Honor of Gerasimos Santas, ed. Georgios Anagnostopoulos. Springer Philosophical Studies 117 (2011), 165-184, on these two varieties of the Knowledge Alone Alternative.

${ }^{19}$ Die sokratische Frage: Platons Laches (Berlin: Lit Verl., 2007). 
The century and a half of scholarly defense of the Wise Endurance Alternative has proved unable to solve this problem. Fröhlich (2007: 140) is right to say that such a definition of courage "would crumble under Socratic examination, if [the endurance in question] were not grounded upon appropriate knowledge of the good." ${ }^{20}$ As it happens, some scholars do ground the endurance in question upon the appropriate knowledge of the good. Thus Devereux (1992: 783): "Once we see the particular way in which [Socrates] understands the power of knowledge [...] we can see that endurance is a necessary concomitant of knowledge of good and evil." The endurance Devereux has in mind - the endurance that is a "necessary concomitant of knowledge of good and evil" - will invariably endure not in a particular course of action but in tracking the human good, all things considered. The infantryman who wisely runs away endures in this sense. The rescue worker who wisely abandons the search endures in this sense. And the scholar who wisely gives up his position endures in this sense. But such endurance is common to other virtues. It is a necessary concomitant, for example, of soundness of mind, of righteousness, and of reverence to endure in tracking the human good. In general, as Devereux (1992: 783) says, "the Socratically virtuous person has endurance, or what we might call 'will power'; but this power does not derive from the will, but [...] from one's knowledge of the good." Such a result naturally leads us to consider the alternative Ethical Theory Interpretation, which defines courage in terms of knowledge alone.

The great advantage of the Knowledge Alone Alternative is that it alone survives Socratic examination. Once we admit that we are investigating the courage that is a virtue - that is, a power that in any circumstances produces the human good - it turns out that only expertise at human well-being is this power. It is a consequence of this result that such expertise does not have proper parts, and hence that virtue does not have parts. On the contrary, virtue words - such as courage, soundness of mind, righteousness, reverence, and wisdom - all refer to one and the same power. Such a consequence is disastrous for the Ethical Theory Interpretation.

The Ethical Theory Interpretation takes Socrates in his conversation with Laches and Nicias to aim at developing an ethical theory, namely, an account of courage. Socrates begins his conversation with Laches by forming an agreement that courage is a

20 This paper is in debt to Fröhlich for her critical review of the German alternative interpretations of the Laches. 
mere part of virtue, and he reiterates this agreement at the start of his conversation with Nicias. These agreements are hard enough to explain - we are driven to suppose that, somewhere in the course of the developing theory, Socrates rescinds this agreement. But, as Devereux (2006: 328-9) explains, such efforts are futile. According to the Knowledge Alone Alternative, "the final argument of the Laches is designed to show that courage is not a part of virtue, but rather is identical to the whole of virtue. However, the conclusion of the argument is hard to square with this view: Socrates says that since courage is a part and not the whole of virtue, we must reject the definition proposed by Nicias (199e3-11)." If Socrates is developing an ethical theory at this, the end of the dialogue, the premise that courage is a part and not the whole of virtue is certainly still a part of the developing theory. The futility of reconciling the Knowledge Alone Alternative with the Ethical Theory Interpretation should lead us to abandon or revise the project. There are two revisions at hand.

Some interpreters try to avoid the problems facing the Wise Endurance and Knowledge Alone alternatives by proposing that Socrates, either wittingly or unwittingly, uses the word courage ambiguously in the Laches. Paul Woodruff attempts to reconcile the seeming contradiction between the statements that courage is only a part but also all of virtue. ${ }^{21}$ Woodruff distinguishes courage in essence (courage-itself) from courage in accident (courage-in-ingots, as it were, on the model of the distinction between the substance gold, which is all one, and gold-in-ingots, which has as many parts as there are ingots). According to this distinction, some things can be true of courage-in-ingots that are not true of courage-itself. For example, it may be that the predicate knowledge only of future goods and evils is true of courage-in-ingots but false of courage-itself.

Unfortunately, Woodruff's distinction does not escape Socrates' argument. To see why, let us accept Woodruff's distinction and make Woodruff's assumption that when Socrates speaks of courage as a part of virtue, he is speaking of courage-in-ingots, not courage itself. Accordingly, courage-in-ingots is a part of virtue. Moreover, as Socrates and Nicias agree, this very courage-in-ingots will be nothing but the knowledge or science of future goods and evils. And it is undeniable, as Socrates and Laches rightly agree, that there is no distinction between the science that knows future

21 "Socrates on the Parts of Virtue", in: Canadian Journal of Philosophy 2 (Supplementary, 1976): 101-116. 
goods and evils and the science that knows goods and evils past, present, and future (198d, 199a). Thus in whatever sense courage-in-ingots is the science of future goods and evils, it is precisely also the knowledge of all goods and evils, past, present, and future. It follows that courage-in-ingots is the whole of virtue, which contradicts Woodruff's interpretation. ${ }^{22}$

Thomas Brickhouse and Nicholas Smith (2010: 157-166) find a different ambiguity. ${ }^{23}$ In the Laches, the words courage and virtue sometimes mean the power (dunamis) of courage or virtue, and sometimes mean the deeds (erga) of courage or virtue. On the one hand, the definition of the dunamis courage as knowledge of what is and is not to be feared (i.e. the knowledge of future goods and evils, i.e. the knowledge of good and evil, i.e. the dunamis virtue entire) is correct. And the proposition that the erga of courage are but a part of the erga of virtue entire is also correct. The thesis of Brickhouse and Smith is that, by means of this ambiguity, Socrates can reconcile the seemingly conflicting claims that courage is knowledge alone and is a proper part of virtue.

Unfortunately, the ambiguity fails to reconcile Socrates' claims. For Socrates is speaking unambiguously of courage as dunamis in both claims. As Brickhouse and Smith affirm, courage as dunamis is nothing but the knowledge of good and evil. But at 190c, the star passage where Socrates secures agreement that courage is a proper part of virtue, Socrates is speaking first of sight, then of virtue, then of the whole of virtue, then of courage, in every case unambiguously as powers (dunameis). ${ }^{24}$

\footnotetext{
${ }^{22}$ Rudebusch 2011 gives this criticism of Woodruff's alternative.

${ }^{23}$ Socratic Moral Psychology (Cambridge: Cambridge University Press, 2010). For a similar ambiguity, see also Michael Ferejohn, "The Unity of Virtue and the Objects of Socratic Inquiry", in Journal of the History of Philosophy 20 (1982), 1-21; and "Socratic Virtue as the Parts of Itself". Philosophy and Phenomenological Research 43 (1983-84), 377-88. Brickhouse and Smith, "Socrates and the Unity of the Virtues", in Journal of Ethics 1 (1997), 311-23; and C.C.W. Taylor, Socrates: A Very Short Introduction (Oxford: Oxford University Press, 2000), 67-68.

${ }^{24}$ There is a red herring in Brickhouse and Smith's exposition. At times they speak as if not ambiguity but the singular nature of the relation between pure and applied science is the key to reconciling the conflicting statements about the 'pure' knowledge of good and evil and the 'applied' knowledge that is courage. The example they give (2010: 164) is mathematical triangulation as opposed to navigational triangulation. "One would look in vain for any difference between them, as they both use precisely the same knowledge - the knowledge of triangulation." But certainly there is a difference. Navigational triangulation needs to know more than pure or mathematical triangulation: for example, it needs to know that stars are fixed points and that clouds are not. In general, any application of mathematical triangulation needs to know more than pure triangulation. Jörg Hardy, in Jenseits der Täuschungen-Selbsterkenntnis
} 
The above alternatives of the Ethical Theory Interpretation - Wise Endurance, Knowledge Alone, and Ambiguity - agree that, in the words of Steinhart (1850: 354), "all aspects of the concept they seek are explicitly stated in the course of the investigation, just as it stands." The agreement is that Socrates completely develops all the pieces of the virtue theory, though the artful construction of the dialogue leaves it to the reader to assemble the pieces. The final alternative of the Ethical Theory Interpretation we consider is that the theory present in the dialogue is incomplete.

For example, Max Pohlenz (1872: 29) holds that Socrates merely raises the question in the Laches "whether courage can still be conceived as a part of virtue as a whole (Gesamttugend) or is identical with it. ${ }^{, 25}$ Likewise Rudolf Meister. ${ }^{26}$ Pohlenz and Meister both agree that, though the theory developed in the Laches is incomplete, it is possible already to see in it the outlines of a theory completed elsewhere in Plato's writings. Unfortunately, just what theory Plato is already at work on but yet to finish and where to look for its further elaboration is unsettled. The disagreement between the Wise Endurance and the Knowledge Alone alternatives repeats itself among these interpreters. For Pohlenz, the completed theory is the reduction of all virtues to knowledge of the good, a reduction Pohlenz finds in the Protagoras. In contrast, Meister (1921: 108) sees the outlines of a different theory in the Laches, namely, the account of courage at Republic $430 \mathrm{~b}$ as the power in the soul that unfailingly preserves right and lawful belief about what is and is not to be feared.

The Incomplete Theory Alternative needs to provide an explanation why Plato would write such a dialogue. Perhaps it is a "record of honest perplexity" (Vlastos 1954: $353)^{27}$ or is a kind of advertisement to attend Plato's Academy, ${ }^{28}$ or has a "mnemonic

und Selbstbestimmung mit Sokrates, Göttingen: V\&R, 2011 (116-136), defends yet another ambiguity alternative. The ambiguity for him is that sometimes Socrates uses the word courage in an extensional sense (denoting the very same as the word virtue in this sense) and sometimes in an intensional sense (denoting a mere part of virtue). Hardy 2011: 128 deploys these terms (about slightly different theses): "The statements are indeed extensionally equivalent, but not intensionally equivalent (extensional gleich, aber nicht intensional gleich)." Hardy 2011: 124 also speaks of courage as one thing having two aspects, depending upon which perspective it is seen from. "As agents (handelnde Personen) we perceive courage as the [...] wise endurance that Laches had in view. Nicias, on the other hand, appears to take a view of things that is detached from agency."

${ }^{25}$ Aus Platos Werdezeit: Philologische Untersuchungen, Berlin: Weidmann, 1872.

26 "Thema und Ergebnis des Platonischen Laches". Wiener Studien 42 (1921), 103-114.

27 "The Third Man Argument in the Parmenides" in: Philosophical Review 63 (1954), 319349. 
function": "a memory aid for those coming to know" (Erler 1987: 60), or any number of other possibilities. Why the insiders would bother to read these advertisements when they could already have the 'real thing' is anybody's guess. One is reminded of Diogenes' quip to Hegesias, who had asked the former for one of his writings, "You are a simpleton, Hegesias; you do not choose painted figs, but real ones; and yet you pass over the true training and would apply yourself to written rules" (Diogenes Laertius, Lives of the Eminent Philosophers, 6.48).Consider, for instance, one more possibility, albeit an extreme one. One might even take Plato's disavowal of authenticity in the Seventh Epistle seriously and view his written corpus as playful, fictional sport, antiadvertisements, perhaps even prototypical disinformation or black propaganda to keep those who have not been properly initiated and prepared for the true, oral teaching busy and preoccupied with something else, the way one gives children playful tasks in order to tire them out. In which case maybe only those who saw through the ruse and realized it was not serious might be suited for his esoteric teaching. This would make those of us who have studied and do seriously study it the butt of one of the most colossal swindles imaginable, were it not for the simple fact that, whatever Plato intended and whatever he may have thought of his own written work, it represents one of the pinnacles of philosophical thought within the Western tradition. Authors' own opinions of their work, and what they consciously intend thereby, are notoriously unreliable. Suppose Plato did consider his written work to be merely amusing trifles, not worthy of posterity. History has judged otherwise, and as with the work of Kafka, it deservedly has had the last word even if against the author's own explicit intentions. Such possibilities for why Plato would write dialogues in which an incomplete ethical theory is present lead to alternatives to the Ethical Theory Interpretation as a whole, rather than alternatives within that interpretation.

Santas claims that prior to the discussion on courage, Socrates is established as "... an expert in a search for the nature of courage" (1971: 181). Socrates alone knows what to look for, namely, a definition that holds, and he also has a method for reaching such a definition, namely, asking the right questions, and posing counter-examples to test the consistency of hypotheses (1971: 183). In the end, Santas concludes, the dialogue succeeds in presenting us with almost all the right questions, but no

${ }^{28}$ As for example Gaiser 1959, Krämer 1959, and Charles Kahn, Plato and the Socratic Dialogue: The Philosophical Use of a Literary Form (Cambridge: Cambridge University Press, 1998). 
satisfactory answers (1971: 208). Which is why, perhaps, it ends with a promise of continuing later, he notes. The only problem with this view is that the characters within the dialogue promise each other to continue their investigation later, but Plato, the author of the dialogue, has given us a complete, finished, and polished work that deliberately, as with other aporetic dialogues, ends in perplexity.

\section{The Theory of Knowledge Interpretation}

The Marburg Neokantians (such as Hermann Cohen $1878^{29}$ and Natorp 1903) proposed a radical reinterpretation of the Laches. For Natorp (1921: 390) it is "as plain as day" that Plato has been "completely misunderstood." 30 All prior interpretations, from Aristotle onward, fundamentally misinterpret Plato's work as a whole, because they do not recognize that Plato's forms are Kantian categories of thought. The virtue dialogues, investigating the nature of moral knowledge, set the stage. Thus about the Laches, Natorp (1921: 10) says, "in the investigation, penetrating ever deeper, of the concept of that knowledge in which, according to Socrates, virtue consists, we will see unfold, step by step, the distinctive Platonic concept of knowledge." According to Natorp (1903: 19), the Laches contains a correction, "at least a clarification", of the account in the Protagoras. In the Protagoras (at 356b-e) moral knowledge is "calculation based upon measurement of the pleasant and unpleasant consequences of actions", a "felicitous prediction of the temporal, empirical consequences of our actions." But in the Laches, the knowledge that is virtue is a "knowledge of a good that is one, that is at all times the same, that is immutable and independent of temporal distinctions" (1903: 19). "In this insight lay the germ of an idea" (1903: 20)—namely, a principle of Plato's laws of thought as he developed them in other dialogues.

According to Natorp (1903: 20-21), in writing the Laches Plato was aware of an "inner conflict" in "the two basic motives of the Socratic: on the one hand the ignorance of virtue and inability to learn, on the other hand virtue's unity with knowledge, which demands teachability." Natorp (1903: 21) sees Plato solve this problem in the Meno, "which, with the thesis of knowing as recollection - the most primitive version of the theory of forms, described in mythical terms - finally answered, and in doing so made

\footnotetext{
29 "Platons Ideenlehre und die Mathematik". Reprinted in Schriften zur Philosophie und Zeitgeschichte ed. by A. Görland and E. Cassirer, vol. 1, Berlin, 1928 (336-366).

${ }^{30}$ Platos Ideenlehre: Eine Einführung in den Idealismus, $2^{\text {nd }}$ edition (Leipzig: F. Meiner, 1921).
} 
obsolete, the problem of teachability that completely dominated the early dialogues." If this were so, Natorp needs a better explanation as to why the Theaetetus, generally considered to come after the Meno, concerns the question of knowledge and ends aporetically and only refers, if at all, cryptically to recollection. ${ }^{31}$ Had Plato solved the Socratic tension between our being in, at best, a condition of self-aware ignorance and the need for knowledge in order to be virtuous one would have expected the insights of the Meno to be carried forward into the Theaetetus.

Natorp (1903: 21) finds other evidence that the Laches is better interpreted as part of a search for a theory of knowledge than of ethics in its methodology, which "is continually drawn to definition."

It annoys the brave soldier Laches that he, asked what courage is, thinks he definitely has it in mind, but nonetheless does not know how to grasp it in words and say what it really is (194b) which in technical terms means to define (properly, delimit, 194c). The technical term is instructively explained by the example [of speed, in order to illustrate] what is needed to find a definition, what is the same in every case $[\ldots]$, what identical basic nature runs through every instance (1903: 21).

The dialogue's discussion of definition uncovers the "definite, systematic opposition of the unity of the concept to the multiplicity of the cases, cases that are connected precisely through that unity to totality" (1903:21). For Natorp (1903: 21), the evidence confirming his epistemological interpretation of the Laches is what he calls its "most important achievement in the end: the unity in the concept of established knowledge" throughout temporal diversity: "Socrates shows that the knowledge in general of a thing is nothing different for past, present, and future, but is one and the same (198d)", foreshadowing "the immutable eternal" as the proper object of knowledge in Plato's theory of forms.

Natorp (1903: 22) takes this, the last positive result in the dialogue, to explain the subsequent perplexity, with which the dialogue ends: "it was far more important at the time to note that the knowledge in which virtue as a whole consists is not the empirical knowledge of what once was, now is, or in future will be, especially not the knowledge [described at Protagoras 356b-e] of anticipated pleasant and unpleasant consequences; but rather to note that its object is always existent, at all times one and the same: the eternal Good."

${ }^{31}$ Timothy Chappell, in Reading Plato's Theaetetus (Indianapolis: Hackett, 2004), plausibly argues against there being a reference to the Meno's account of recollection in the midwifery passage of the Theaetetus (46-47). 
Natorp's interpretation of the Laches is part of an overall account of Plato as developing from a Socratic to a proto-Kantian philosopher. Without calling into question the premises Natorp assembles in his account, we point out that Natorp's explanation of the form of the Laches is deficient. If it is Socrates' aim within the dialogue (or Plato's aim in writing the dialogue) to develop a theory not of virtue but of knowledge, then we ought to expect the dialogue to end with its positive result about the universality of knowledge, rather than in perplexity about courage. As Fröhlich (2007: 166) puts the objection: "the definition of knowledge, which should be the goal and result of the discussion, is not formulated at the end or articulated"-allowing her to ask (2007: 166-7): "Where does one find that Platonic knowledge of knowledge (Wissen von der Erkenntnis) that Natorp stated to be goal and result of the dialogue?" It is implausible that Socrates' premise about the universality of knowledge is the aim of the dialogue as a whole. That Plato was perfectly capable of writing a dialogue that does explicitly concern knowledge should be clear from the Theaetetus. Even were he to turn there, though, Natorp would have to grapple with why that dialogue, too, ends aporetically.

\section{Fruitlessness Interpretations}

Hiestand (1923) has a simple and powerful argument against any interpretation that finds in the Laches the development of a theory, whether an ethical theory or a theory of knowledge: if the dialogue develops theoretical knowledge, then there must be progress towards that goal within the dialogue. But there is no such progress: the search in the dialogue is fruitless.

Hiestand finds four substantive Socratic propositions in the Laches:

1. Courage is a part of virtue.

2. Courage is something good.

3. Only wise endurance is good.

4. Someone is good in that in which he is wise.

Hiestand (1923: 38) notes that these four propositions are not proved and describes them as "called into question during lengthy discussions, but neither rejected nor established as correct (als richtig anerkannt)." He thinks that the contradictions between moral requirements and everyday experience remain unresolved in the dialogue, and that the perplexity at the end is real. He (1923:38) describes the result of the dialogue as a whole: "military leaders — experts, we ought to suppose — find no 
conclusive answer. Socrates himself does not know how to solve the contradiction. Therefore in both cases there is just one inescapable conclusion (unerbittliches Ergebnis) for all participants: the recognition of ignorance."

The "often expressed result" of Socratic examination in general is this "ignorance" (1923: 88). Accordingly, Hiestand (1923: 41) finds in the virtue dialogues not a single "clear result or a definite step in the direction" of a result. "Neither for Socrates nor for the interlocutor is there in the course of the dialogues an intellectually positive achievement" (1923: 41). Thus, as Fröhlich (2007: 153) reports, Hiestand's Socrates was not trying to develop a definition at all, but rather "wanted to bring the interlocutor to that insight into ignorance or self-awareness that he himself had obtained. The Socratic question aims to unmask the educational and moral knowledge of the interlocutor as mere appearance (Scheinwissen) and thereby to free him from vanity and conceit and to inculcate humility."

That Socrates in the Laches aims to unmask ignorance, rather than develop any theoretical account of his own, is also endorsed by the Philosophical Interpretation (see below). What is distinctive to Hiestand's Fruitlessness Interpretation are his further claims (1923: 98) that for Socrates "moral knowledge is impossible" and in particular that such a goal is "something fruitless and empty" (Unfruchtbares, Leeres). Thus Socrates presumes to unmask our phony goals, but puts "no other creative deed in their place", leaving us "therefore only the bleak insight in our own inability (Unvermögen)", with the result that "this Socrates must become weary; death can bring him nothing more bitter" (1923: 101).

Hiestand's distinctive claims about bitter fruitlessness are, as Fröhlich (2007: 157) points out, at odds with Socrates' "reflective search for knowledge" and in particular his repeated exhortations to others to live lives of reflective philosophical examination. Other alternatives, accepting the point that the virtue dialogues do not develop theoretical accounts, seek to find something more positive than bitter fruitlessness. Furthermore, Hiestand has overlooked Socrates' own response to Laches' grappling with perplexity after the latter's refutation (at 194a). Laches, as one might read him, can be seen to feel something of this bitter fruitlessness when he complains that though he feels he knows what courage is he cannot put it into words, cannot harmonize his logos with the courageous erga he has himself performed and seen others, such as Socrates, perform. If Socrates simply negated the pretensions of his interlocutors and left them with no alternative other than skepticism, why does he exhort 
Laches to continue in the search for knowledge of courage after refuting him? Why does he suggest a hypothetical, if only playful, definition of courage himself at this point? If the point was simply to lead others to a recognition of their own vanity we would expect him, according to the Fruitlessness Interpretation, simply to leave Laches alone at this point and move on to his next target, Nicias.

A different version of the Fruitlessness Interpretation, in which the bitterness of arriving at insight into our ignorance is mitigated by emphasizing our negative capacity to critique customary beliefs in individual and novel ways, which we call the Think for Yourself Alternative, is found in Hegel and Grote. Here, since one cannot attain objective knowledge, since such an attempt is shown in the dialogues to be fruitless, the best one can hope for is the cultivation of the capacity of thinking for oneself. In other words, the barrenness of acquiring objective knowledge is mitigated by the fruitfulness of self-enrichment, the enhancement of subjectivity. Hegel (1848: 328) proposed that "it is in Socrates that $[\ldots]$ the principle of subjectivity (Innerlichkeit) - the absolute independence of thought in itself - attained freedom of expression. He taught that man has to find and recognize in himself what is the right and good, and that this right and good is in its nature universal. Socrates is famous as an ethics teacher, but he is, rather, the inventor of ethics." Hegel's Socrates is, in the words of Frank M. Turner, "a radical, self-conscious opponent of [..] the rule of custom, religion, emotion, and prescription, which Hegel had associated with Sittlichkeit" (1984: 295), ${ }^{32}$ that is, conventional morality. Hegel does not provide specifics to develop the abstract proposal about Socrates' expression of subjectivity.

Grote provides one way to understand Hegel's abstractly stated interpretation. Like Hegel, Grote's Socrates is an opponent of blind acceptance of external prescriptions of behavior. Accordingly, Grote denies that "negative dialogues" such as the Laches seek to develop theories. In some passages (e.g. 1885: 418) Grote seems to accept the bitter fruitlessness interpretation: "this then is the mission and vocation of Sokrates -1 . To cross-examine men, and to destroy that false persuasion of wisdom and virtue which is so widely diffused among them. 2. To reproach them, and make them ashamed of pursuing wealth and glory more than wisdom and virtue. But Sokrates is not empowered to do more for them."

\footnotetext{
${ }^{32}$ The Greek Heritage in Victorian Britain (New Haven: Yale University Press, 1981).
} 
Grote (1885: 420) does nonetheless find that both Socrates and Plato "had affirmative doctrines and convictions, though not both the same. But the affirmative vein, with both of them, runs in a channel completely distinct from the negative. The affirmative theory has its roots aliunde, and is neither generated, nor adapted, with a view to reconcile the contradictions, or elucidate the obscurities, which the negative Elenchus has exposed." Accordingly (1885: 421), "The negative cross-examination, and the affirmative dogmatism, are (both in Sokrates and in Plato) two unconnected operations of thought: the one does not lead to, or involve, or verify, the other." But Grote (1885: 421) finds Socrates' positive doctrines in such places as the "Xenophontic Memorabilia", not the Laches.

Despite his claim that Socrates cannot do more than destroy and reproach, in the case of negative dialogues like the Laches, Grote (1885: 421) attributes something more to Socrates than bitter fruitlessness, namely, "the creation and furtherance of individual, self-thinking minds, each instigated to form some rational and consistent theory for itself." For Grote (1885: 421) this result “is a material benefit, even though no further aid be rendered to the process except in the way of negative suggestion.

That such minds should be made to feel the arbitrary and incoherent character of that which they have imbibed by passive association as ethics and aesthetics, - and that they should endeavour to test it by some rational and consistent standard-would be an improving process, though no one theory could be framed satisfactory to all. The Sokratic Elenchus went directly to this result.

Subjectivity, that is, thinking for oneself, even if one's thoughts are unsatisfactory to some others, is Socrates' aim in the Laches. Such subjectivity is a very modest improvement upon bitter fruitlessness. Surely Socrates himself would deny that such thinking for oneself is a benefit for any human being.

For every man who knows not how to make use of his soul it is better to have his soul at rest and not to live, than to live acting according to his own caprice; but if it is necessary for him to live, it is better after all for such a one to spend his life as a slave rather than a free man.

This quotation is from a speech Socrates makes at Clitophon 408a-b, whose author is either Plato or a student of Plato and who accurately summarizes Socrates' conclusions as Plato presents them at Euthydemus 278e-282c. According to Xenophon (Memorabilia 1.2.49-50), Socrates at trial was accused of arguing for the lawfulness and beneficence of the wiser imprisoning the more ignorant. Socrates values not 
subjectivity but wisdom. Thinking for oneself is irrelevant in and of itself; what matters is that one thinks the truth.

\section{Praxis Interpretations}

We next consider several interpretations that share a concern with emphasizing the non-theoretical display of virtue by Socrates in the dialogues, varieties of what we call the Praxis Interpretation. Whether the activity is one of ineffable insight, or a kind of knowing ignorance that is displayed by Socrates for the benefit of his interlocutors and for us as readers, or an entire way of life that one can adopt for oneself, each of these interpretations holds that Socratic philosophy is fundamentally a practice and not a theory, fundamentally a matter of attaining insights that cannot be reduced to formulae but are learned by imitating a model. One such version of the Praxis Interpretation, The Ineffable Knowledge Interpretation, like the Know Nothing and Think for Yourself interpretations, denies that the aim of a Socratic conversation like the Laches is to develop a theoretical account of virtue (or knowledge). Nonetheless Socrates' aim there is the development of wisdom, a wisdom that is not the propositional knowledge of a theory. Instead it is a kind of knowledge that theoretical statements in important ways cannot capture. ${ }^{33}$

The following reasoning seems to lead to this interpretation:

1. There must be something more positive to be learned from Socratic dialogue than bitter fruitlessness!

2. But there is evidently no progress in theoretical knowledge in a Socratic dialogue.

3. Thus there must be progress in non-theoretical knowledge.

According to Friedländer (1928: 44), "it is wrong to see the Laches simply as an investigation concerning the nature of courage, to see its issue as a definition that one might suppose is easy to formulate out of the basic approaches in that investigation. In contrast, the overall meaning of the slice of world which is pictured [in the Laches] is far more accurately characterized by the word education" than as the development of a

${ }^{33}$ Proponents include Julius Stenzel, "Wissenschaft und Staatsgesinnung bei Platon" (Kiel: Lipsius und Tischer,1927) and Platon der Erzieher (Leipzig: Meiner, 1928); Friedländer 1928, Werner Jaeger, "Die platonische Philosophie als Paideia", in Das Platonbild: Zehn Beitrage zum Platonverstandnis, ed. K. Gaiser (Hildesheim: G. Olms, 1969); Wolfgang Wieland, Platon und die Formen des Wissens, $2^{\text {nd }}$ and $3^{\text {rd }}$ editions (Göttingen : Vandenhoeck \& Ruprecht, 1982 and 1999, respectively) and Fröhlich 2007. 
theory or as a theoretical investigation. For Friedländer (1928: 44) the "theoretical investigation concerning courage" is just a part of the "total educational process"- a process that leads not to a theory, nor to fruitlessness or subjectivity, but in the best case to a life of virtue, which is the examining life. ${ }^{34}$

Non-propositional knowledge might be either practical know-how or it might be knowledge by acquaintance. Friedländer proposes that the goal of a Socratic dialogue is both. On the one hand - as to the goal being a kind of know-how — Friedländer (1928: 64) describes the goal of Socrates' activity as the activity of that life itself, a life spent examining oneself and others.

What Socrates asked was, to Plato, both question and answer; what Socrates lived was both his life and his teaching. Socrates asks: what is [courage]? He lets others see that they do not know. He seeks the answer in thought but he gives it at last in his life and death $[\ldots]$. That is the answer to Socrates' question, to be read in the reality that Socrates was. ${ }^{35}$

The wisdom Socrates seeks, then, is a wisdom that he already possesses and exemplifies. Friedländer cannot take at face value Socrates' profession of ignorance. Instead he (1928: 162) interprets Socrates' profession of ignorance as an expression of "the impossibility finally to say (in Worten allerletzt zu sagen) what the righteous is." It is this ineffability of wisdom that underlies the "knowledge of the lived life" (1928: 156), a life that Friedländer (1928: 162-3) describes as the "being of the righteous man, which raises him to the level of the gods."

On the other hand - as to the goal of a dialogue being knowledge by acquaintance - Friedländer's interpretation of Socrates is connected to his interpretation of Plato, a Plato who has no theory of Forms but somehow still offers us a

${ }^{34}$ Like the Philosophical Interpretation (defended below), Friedländer interprets Socrates intentionally to direct the discussion to a false start in every dialogue where he seeks to define a part of virtue. Fröhlich (2007: 182) criticizes such an interpretation by asking the rhetorical question: "Has Socrates in all the virtue dialogues intentionally posed a false question?" Unlike the Philosophical Interpretation, Friedländer lacks the resources to explain why Socrates would do such a thing.

35 One can object that Friedländer and others sharing this view shift the problem of interpretation from a textual/theoretical one to a lived and embodied/practical one. Since we allegedly get no clear answers to the theoretical questions, we are supposed to look to how Socrates lived and conducted himself (as providing the hidden 'answer'). Clearly, the Cynics did this. But, Socrates' life and conduct have themselves been the subject of various interpretations and emphases (Aristippus, Antisthenes and Plato would presumably all in some sense claim to be following the example of Socrates but they live and practice fundamentally different philosophical projects). Now, instead of arguing over Plato's/Socrates' theory in the dialogues we argue over what Socrates as living example signifies. 
vision of the Forms - that is, a knowledge by acquaintance. Through Socratic conversations and in the person of Socrates himself, Friedländer's Plato sees Courage Itself. For those who have seen the Forms, there is only a single task: "to open the eyes of others to what you have seen" (1928: 21). "The whole Platonic corpus is an effort to bring us "to a vision of the Form [der Idee] and to an intimation of the highest good" (1928: 68) with the goal of reforming individual and state.

Friedländer (1928: 57) unites the wisdom that is know-how and the wisdom that is knowledge by acquaintance in the following way. The knowledge by acquaintance or "vision" of the Forms cannot be expressed in the words of a theory but in the activity of a life: living and knowing are "linked into an inseparable unity." 36

Any such interpretation must ignore an important feature of Socrates' craft analogy. It is true that we cannot present in a list of theoretical statements everything significant about the practical activity of the farmer, say, or the general. But, Euthyphro's inability notwithstanding (Euthyphro 13e-14b), we still expect an expert to be able to sum up what the goal of such activity is: food from the earth or victory in war. Likewise we are entitled to expect of a person with expert practical know-how about courage to give a competent account of what courage is. As Socrates repeatedly says (e.g. at Charmides 158e-159a) about human excellence, if you possess it, you ought to be able to say what it is. This unfaithfulness to the text is a defect of the Ineffable Interpretation. Were this interpretation correct, in the Laches we would expect Socrates to accept Laches' excuse that the latter cannot put into words his definition of courage, though he still believes he 'knows' what it is (at 194b). Even more, we would expect Socrates to say to Laches something like "You're beginning to understand the point of what we're doing!" The fact that Socrates does not accept Laches' excuse and carries through his refutation argues against Friedländer's interpretation. Indeed, if Friedländer were right, then the theme of harmonizing one's words and deeds would not play the prominent role it does in the Laches. If wisdom is ultimately ineffable, then

${ }^{36}$ Like Friedländer, Fröhlich (2007: 157) distinguishes "theoretical knowledge" (theoretischem Wissen) from the "ineffable knowledge" (kein aussagbares Wissen) that is the goal of a Socratic dialogue. Like Friedländer, she (2007: 269) sees that knowledge as both know-how (namely, "skill at examination", Prïfungskompetenz) and knowledge by acquaintance (described as "nonconceptual insight", nicht-begriffliche Einsicht). Like Friedländer, she (2007: 270) sees "virtuous being" (tugendhaften Seins) in the Socratic act of "examining and seeking": "the course of the dialogue shows that Socrates exercises courage." And like Friedländer, she (2007: 271) unites knowledge by acquaintance with know-how in action: Socratic dialogue is "a unity of knowledge and life experience, of theory and praxis. The virtue discussed in dialogue is not merely viewed but realized." 
there would be no need to worry about whether one's deeds and words are in harmony, for virtue would not be able to be put into words. One would simply act virtuously without being able to give it utterance in speech.

In addition, any interpretation that, like Friedländer's or Fröhlich's, identifies the philosophical life with a virtuous life conflicts with Socrates' account in the Apology of three levels of wisdom.

The highest level is "real wisdom" (23a5-6), which is the property of God, not human beings. The middle level is being "wisest among men" (23b2), which is the property of anyone who, like Socrates, "knows that he does not possess real wisdom of any value" (23b3-4). The lowest level is "not being wise, but seeming wise, especially to oneself" (21c6-7). Socrates is as wise as a mortal can be - no one is wiser - because only God possesses wisdom and because Socrates is significantly wiser than people who are ignorant even of their ignorance (Rudebusch 2009: 20).

Socrates knows that, being ignorant, he is unable to teach people virtue. This is why he refuses to accept payment for his time. Bringing people from the lowest level (which is bad) to the middle level (which is neither good nor bad) is the best he can do. Such an achievement is a significant gain - it removes the guilt of reckless, albeit unintentional, wrongdoing from our life. ${ }^{37}$ But Socrates neither teaches nor shows us how to be virtuous. A better interpretation will be more faithful to the text.

Characteristic of the Praxis Interpretation is the view that the ultimate purpose of the dialogues is to model for us a philosophical way of life. Pierre Hadot gives another version of this interpretation. Based upon remarks of Plato in the Seventh Letter and the myth told in the Phaedrus, Hadot claims that Plato's written dialogues were not intended as serious philosophical works but are rather "works of propaganda, decked out with all the prestige of literary art but intended to convert people to philosophy" (2002: 72). ${ }^{38}$ Like Gaiser 1959 and Krämer 1959, Hadot views the dialogues as advertisements for prospective philosophy candidates, as instruments of their conversion. Plato chose to write dialogues because the Socratic dialogue was "very fashionable at the time" and because such a dialogue, with Socrates as principal, best displays what Hadot (2002: 72) calls the "ethical value of dialogue." In other words, the kind of discussion that Socrates and his interlocutors have in Plato's dialogues is a model for the lived practice of similar discussions that we as aspiring philosophers

\footnotetext{
${ }^{37}$ It is thus a positive accomplishment in the sense of moving us from a worse condition of unwitting culpability into a better one of 'doing no harm'.

${ }^{38}$ What is Ancient Philosophy? Cambridge, MA: Harvard University Press, 2002.
} 
should have. The dead letter of the written dialogues captures something of the living spirit of oral discussion within the Academy and the reading of the former is supposed to spur us on to the lived practice of the latter. The written dialogues' purpose is to improve one's powers of reasoning, so that a student can "master the arts of measure and definition in every domain" (2002: 73). There are elements of Plato's philosophical doctrine scattered throughout the dialogues but what is fundamental is that they train students to live ethically by inculcating the acceptance of values such as the importance of defining a form or idea in order for rational discussion to be possible, so that we are actually talking about the same thing with each other. Hadot also sees Plato's dialogues as showing "the Norms...the Forms, or Reason, or the Good, or Beauty" (2002: 75) but not explicitly stating what they are.

Hadot sums up his view as follows: "There was a Socratic style of life (which the Cynics were to imitate), and the Socratic dialogue was an exercise which brought Socrates' interlocutor to put himself in question, to take care of himself, and to make his soul as beautiful and wise as possible. Similarly, Plato defined philosophy as a training for death, and the philosopher as the person who does not fear death, because he contemplates the totality of time and of being" (1995: 269). Philosophy, on Hadot's account, is fundamentally something one does, a lived practice, an ethical comportment toward oneself, others and the world. Plato's philosophy was a way of life, and the dialogues can help us identify features of this way of life. Once more, this merely shifts the problem of interpretation from a supposed implicit theory to a supposed implicit praxis or way of life. Three problems arise here. First, which practices matter most and why? Second, what are these practices, in a concrete sense? If the members of Plato's Academy practiced memory exercises and routinely argued in a specific manner, it is hardly clear why this is supposed to be the ultimate point of the dialogues. Finally, Leo Strauss has pointed out, in the course of arguing for a version of the Ethical Theory interpretation, that there can be no Socratic way of life that we may emulate because we seem to lack a fundamental feature of Socrates' life, namely his daimonion. ${ }^{39}$

Foucault (2011: 121-155) offered a reading of the Laches that is indebted to Hadot's interpretation. He sees in the Laches three prominent practices of Socratic philosophy: speaking the truth (parrhēsia), examining and testing the soul (exetasis),

\footnotetext{
${ }^{39}$ The point of the dialogues, according to Strauss (51) is: "live as Socrates tells you to live; live as Socrates teaches you to live." In: The City and Man (Chicago: University of Chicago Press, 1978).
} 
and care of the self (epimeleia heauton). Instead of a portrayal of the care of the self as a care for the soul (and an attendant ethics of purification), in the Laches Foucault sees the care of the self portrayed as a test of life, as a putting oneself and others to a test that will reveal their relation to the truth and how that relation may need to be adjusted how one's way of life may need to be changed in order to become able to speak the truth and act in accordance with it. Here the aim of philosophy is not merely to understand the truth but to live it, to make a practice of living in a way that is characterized by speaking the truth and acting in harmony with one's own words. Speaking frankly is a Socratic practice in which the socially prevalent use of manipulative rhetoric and flattery is suspended so that philosophical discourse may take its place. Thus, according to Foucault, the two old men (Lysimachus and Melisias) have set things up so that parrhessia can prevail in their conversation, in order to have a chance to find a genuine answer to their question. They need those who know about courage honestly to tell them if the display of fancy fighting that they have just seen is the sort of thing that can help their sons care for themselves properly so that the latter will bring honor to their family and city. Foucault also reads Nicias' warning to the party (187e-188c) as an apt characterization of the Socratic practice of examination. According to Nicias, Socrates questions a person in such a way as to force them to give an account of themselves and the way they are living and have lived. Socrates invites his interlocutor to explain himself, "to show the relationship between himself and logos (reason)" (2011: 144). In other words, those who are subject to philosophical examination must show that the words that they speak in a discussion, the reasons that they give in an argument, have the right relationship with their way of life, with the actions they choose. The main question is then whether one is living properly, not whether one has made pleasant conversation or been a persuasive speaker. This is what philosophical truth-telling aims to uncover and lay bare. The language Nicias uses to describe Socrates - as someone who "puts to a test" ( $\beta \alpha \sigma \alpha v i ́ \sigma n, 186$ a3) himself and others - evokes the image of a touchstone, that is, a stone used to test precious metals to see if they were genuine. Socrates himself and his philosophical practice, his way of conducting philosophical inquiry in dialogue with others, is a sort of touchstone by which the accounts which others give are tested and it is discovered whether they are genuine, whether they are valuable (like gold) or not. What passes the test is approved as suitable for living well, what fails the test is rejected. As (Foucault 2011: 145-146) points out, the test is not something which happens when one is young and in school but 
is instead something which recurs throughout life; one must always be ready for reexamination and re-assessment. We see this theme of 'late-learning' played out frequently in Plato, of education as a process that one undergoes throughout life. In an unsettling way, Socrates' negative critical scrutiny uncovers philosophical ignorance, a scrutiny that all claims to knowledge and wisdom must be tested against. He is thus not the sort of teacher who passes on positive doctrine to students.

Foucault reads the aporetic ending as suggesting three results: First, Laches' and Nicias' failure to accept their respective refutations is a good sign and entails that they will seek to remedy their flawed understandings of courage. ${ }^{40}$ Next, Socrates over the course of the conversation has been identified as the one most worthy of trust, the one to lead the others toward knowledge of courage - even if he does not know it himself, he is best equipped to help them find someone who does. Finally, Socrates suggests that since none of them have shown that they know what courage is, and since he does not claim to be a teacher with knowledge to share, what is needed is for them all to look for a teacher who can help them. Foucault says that we should not read this as a literal request by Socrates, as though he thought there was actually some person in Athens who could tell them truly what courage is, but rather "This teacher...is of course logos itself, the discourse which will give access to the truth" (2011: 151).

Gonzalez proposes a third version of the Praxis Interpretation. Like Friedländer, he claims that Socrates exhibits the virtue of courage by his conduct in the dialogue (1998: 37). But Gonzalez does not claim that the definition of courage is ineffable. Unlike Laches, Socrates is skilled in the use of argument in the search for truth and capable of looking "beyond experience" (1998: 37). Unlike his two interlocutors, Laches and Nicias, Socrates does not overconfidently take himself to have the ability to argue for a correct definition of courage. Socrates' superiority over his two interlocutors is tied to his professed ignorance, because of which he never assumes based either on his experience or his reasoning ability that he knows anything with certainty. He has "a knowledge which is compatible with ignorance and is not a techne" (1998: 38). Gonzalez interprets Socrates as demonstrating courage in the dialogue rather than successfully defining it. On this reading, courage cannot consist of a moral knowledge of what is good and bad that would eliminate all risks or dangers of uncertainty, since

\footnotetext{
${ }^{40}$ We take it that Plato expected his readers to know both the failure of the two generals to adopt a life of Socratic philosophizing and their consequent downfalls. Accordingly, any remedial efforts they might have made, as Foucault postulates, must have been unsuccessful.
} 
such a knowledge would be open to the same counter-examples Socrates employs with Laches (1998: 39). Courage must be a different kind of knowledge than technai. Unlike technai, courage is compatible with some degree of ignorance. If we had a science of good and bad that allowed us to undertake an action with complete certainty that we were doing the right thing or complete mastery of a skill that reduced all risk, courage would be impossible (1998: 40). Courage has to do with both moral and physical risks, with not being sure of what value in a given instance has priority, with facing the unexpected (1998: 40). Gonzalez reads the dialogue as deliberately not saying what courage is but rather showing what it is, in the life of Socratic "knowing ignorance" (1998: 40). This Knowing Ignorance Interpretation denies that the aim of a Socratic conversation like the Laches is to develop a theoretical account of virtue. Yet there is still a sense in which it takes the virtuous life to be a life not merely of intellectual activity but even of academic discussion, namely, a life of philosophical crossexamination.

Finally, we take Hildebrandt's Will to Power Interpretation (1933) to be a version of the Praxis Interpretation. Hildebrandt's interpretation is voluntarist, not intellectual. He denies not only that Socrates aims to develop any theory in conversations such as the Laches, but also denies that Socrates there is primarily concerned with any intellectual achievement, whether theoretical or non-theoretical. Like Friedländer, Hildebrandt takes Plato's ultimate concern to be political reform in the state. He thinks it is a fundamental mistake to see Plato as intellectually seeking to grasp the logical structure of the world, as one "who disengages from space and time to establish an abstract, eternal system" (1933: 13). Instead he interprets the early dialogues as reflecting Plato's struggle for political power in Athens, writing them in order "to gather, in the space of a few years, followers that would renew the state" and become co-regents with Plato (1933: 105).

In the Laches, Plato portrays two men of war, Laches and Nicias. Hildebrandt (1933: 92) takes Laches to represent the proper nature for a good soldier, and Nicias to represent an incompetent and unsatisfactory nature. Laches "sees in Socrates the stuff that always is operative in the history of spirit, and he sees in the sophist the beautiful appearance that a real man stands against" (1933: 87). Laches has "courage in his blood" not his intellect; he has "what it takes to be a true student of Plato" (Anlagen des echten Platonschülers, 1933: 90). Nicias lacks "creative blood", and unlike Laches he does not recognize that Socrates is the true educator and nation builder. Nicias wrongly 
believes "that we come to excellence and wisdom through merely intellectual learning" (1933: 88).

Hildebrandt thinks the usual scholarly classification of Nicias as a Socratic on the basis of his dialectical skills is a mistake: Nicias's words are "a pseudo-intellectual surface" (1933: 87). Nicias does not understand the statement that virtue is knowledge "in a Platonic sense" (1933: 88). Laches, in contrast, understands Plato's "favorite idea" (Lieblingsgedanke), the "harmony of word and deed" (1933: 87). A powerful ruler's words of authority, the expression of will not intellect, are what has creative power in the world.

The plausibility of Hildebrandt's reading depends upon his thesis that Plato approves of Laches and disapproves of Nicias. Scholars tend to be sympathetic to the idea, taken up by Hildebrandt, that Plato indeed does rebuke Nicias at Laches 198e199a. There Socrates says that "in war the general is the best judge of what will happen, taking heed not even of seers." As Thucydides relates (7.50.4), Nicias as a general deferred to seers with disastrous results. However, as Fröhlich (2007: 197) points out, Socrates just as plainly rebukes Laches at 197e. There, after Laches dismisses Nicias's distinction between fearlessness and courage as sophistry, Socrates says "Nicias seems worthy of consideration" and that "whoever wishes to grasp the greatest things must have a share in the greatest intellect." Again, as Fröhlich (2007: 197) also points out, there is no more evidence that Laches' approved "harmony of word and deed" is Plato's favorite idea than ideas expressed by Nicias, for instance, that courage is knowledge of what is and is not to be feared or that a man is good insofar as he is wise. Finally, it is worth noting as well that while Laches may approve of the "harmony of word and deed", when refuted he admits to Socrates his failure to achieve it. If Laches is supposed to represent an endorsement of the importance of harmonizing word and deed, Hildebrandt needs to explain why Plato represents him as failing to harmonize his own words and deeds.

We agree with Fröhlich's assessment (2007: 198): “If Hildebrandt cannot prove that Plato assesses Nicias as unfit and prefers Laches, then he is subject to the suspicion that it is his own anti-intellectual prejudice that discounts Nicias, promotes Laches, and projects these judgments onto Plato.” As Fröhlich (2007: 205-8) shows, Hildebrandt's interpretation is more accurately attributed to Callicles and Thrasymachus than to Socrates and Plato: "Plato is, according to such an interpretation, nothing but a tyrant" 
(2007: 208). It is no wonder that scholars have largely ignored Hildebrandt's antiintellectual interpretation of Plato since Hitler's defeat in 1945.

\section{The Unwritten Doctrines Interpretation}

Aristotle tells us (Physics 209b) that Plato orally taught some doctrines without writing them down. According to the Unwritten Doctrines Interpretation, the "very heart of Platonic ontology", is composed of certain "principles of doctrine whose application consists in the reduction of all types and relationships of beings to a few simple entities" (Krämer 1959: 455). ${ }^{41}$ As Fröhlich (2007: 233) describes it, "in the logical and mathematical investigations of the inner academy [...] all entities - sensory appearances, mathematical objects, the Forms — are reduced to two opposing principles, and their interactions in the different realms of reality are systematically apprehended through proofs of analogous structures and laws of being." The resulting, unwritten ontology is, according to Krämer (1972: 442 n. 112), "the core and summit of Platonic dialectic, indeed, of Platonic education overall."

Krämer's (1959: 477) distinctive proposal was that "previous research was wrong in ascribing the ontology of principles only to late Plato." Krämer ascribes to the Socratic dialogues three functions: (i) to attract talented students to Plato's Academy, (ii) to earn the respect of the untalented, and (iii) to remind insiders of the oral teachings by reference and hints.

The Unwritten Doctrines Interpretation explains the negative ending of each virtue dialogue as follows: "the appropriate philosophical basis, especially the solution of the problem of the apparent ambivalence and relativity of value, is certainly beyond the written dialogues in the esoteric realm of speculation about ontological principles" (Gaiser 1959: 107). In the case of the Laches, Gaiser (1961: xv) takes the reference to 'going back to school' at the end of the dialogue as further evidence that the dialogue points "beyond itself to a higher knowledge", a knowledge reserved by Plato for oral instruction only in his school. The virtue dialogues are meant to convey "that we must first learn the crucially important [but unwritten] knowledge" taught in the Academy (Gaiser 1959: 116).

\footnotetext{
${ }^{41}$ Other proponents include Gaiser 1959, "Das Platon-Bild Stenzels und seine wissenschaftliche Bedeutung", in Stenzel 1961; Platons ungeschriebene Lehre (Stuttgart: Klett, 1963); Thomas Szlezák, Platon und die Schriftlichkeit der Philosophie (Berlin: de Gruyter, 1985); and Erler 1987.
} 
Erler (1987: 60) adds that the virtue dialogues serve the additional role of "memory aid for those coming to know" - that is, for students hearing oral instruction in the Academy. He proposes that, "whenever the discussion leads to aporia or paradox, the cause is not in the logos itself, but is seen in the understanding of the interlocutor" (1987: 277). The typical mistake of the interlocutor is to fail to understand properly true statements, interpreting them in a false, "this-worldly, technical" way as belonging to the "world of becoming" (1987: 278).

Like the Ethical Theory and the Theory of Knowledge Interpretations, the Unwritten Doctrines Interpretation sees Socrates' goal within the dialogue as a theoryultimately metaphysical instead of ethical or epistemological. Thus Gaiser (1959: 228): "I see proper Platonic philosophy in the first place as converting people to the Form of the Good and thereby joining them to the Divine. The knowledge of virtue consists in the ability to view the principles and norms that are grounded in ontology - this is the aim of Plato's protreptic, logical philosophy" - that is, the virtue dialogues such as the Laches. Unlike competing Theory interpretations, the Unwritten Doctrines Interpretation is able to give a satisfactory account of the negative ending of a Socratic dialogue. As Wieland (1982: 44-5) puts it, "in the dialogues those [solutions] are never revealed, by which we might directly view, as such, the philosophical theory proposed by Plato. Once we are aware of it, it is natural to seek Plato's philosophical theory in another place, for example in his unwritten teachings".

There are two main problems with the Unwritten Doctrines Interpretation. In the first place, as Fröhlich (2007: 234) puts it, "difficulty with sources makes problematic the reconstruction of Platonic esoteric - indeed unwritten - doctrines." What this means is that even if Plato did have an esoteric doctrine and even if the dialogues are only the first step of an educational process that culminates in such a doctrine, in the absence of more reliable evidence regarding that doctrine, we can merely conjecture about it based on what others, with various agendas and axes to grind or at various historical removes from the Academy in Plato's time, have written. Moreover, we trivialize the explicit content of the dialogues we have for the sake of principles, imputed to Plato, concerning which we can only conjecture as to how he would have treated them himself. A few abstract principles or an intellectual vision of these principles or the ontological entities upon which they are based, or a method that leads students to such mystical insight — all these pale in comparison with what the dialogues explicitly provide us. As Wieland (1982: 43) says, "The two sides of any dialogue 
contain in any case far more philosophical substance than anyone has been able to reconstruct as communicable content of the unwritten teachings". In the second place, no bare principle, or handful of principles, will save our lives in the manner Socrates seeks. What we need, rather, is practical expertise at human well-being, analogous to say, the craft of medicine in improving our souls, or to the craft of navigation in guiding us best through life. How would such principles, or a vision that catches sight of the ontologically primordial entities from which they derive, provide practical human expertise at living well in the Socratic sense? Having such a vision that grants one the 'truth' for all time as something now permanently possessed is at odds with the practical life of self-examination and cross-examination of others that is represented in the figure of Socrates, who rather suggests that we do not yet know what we need to, that the truth is still out there for us to discover, that we remain on the way to it, hunting it and chasing it down, and are anything but mystical epopts whose ignorance has been replaced with a kind of revealed knowledge.

\section{The Philosophical Interpretation}

The Philosophical Interpretation takes at face value Socrates' account in the Apology of his life of cross-examination of others. The goal of a Socratic dialogue is to save a life from the guilt of reckless negligence by changing it from bad to neither good nor bad. ${ }^{42}$ According to this interpretation, Socrates is not trying to develop a theorybe it ethical, epistemological, or metaphysical. Nor is he trying to develop nontheoretical know-how or give us a vision of the Form of the Good. His goal is to change non-philosophers into philosophers, by removing the interlocutor's pretence of wisdom about the only thing of real value, human well-being. Even if the philosophical life never acquires wisdom, it is not fruitless. This is because, unlike the non-philosopher, the philosopher lives free from guilt.

Socrates realizes, both on the authority of the oracle and on the basis of his own examination of three classes of men - politicians, poets, and craftworkers - that no human being, but only a god, might possess the highest level of wisdom, namely expertise at producing human well-being (23a). Yet the philosophically examining life at the middle level is worth living, while, as Socrates says, a non-philosophical or non-

${ }^{42}$ On the distinction between good, bad, and neither good nor bad, see Reshotko 2006 and Rudebusch 2011. 
examining life at the lowest level is not (38a). The difference between the middle and lowest levels is that philosophers recognize their own ignorance, while nonphilosophers do not. [reference removed] proposes that the fatal flaw of the lowest level, the non-examining life, is its guilt: as Socrates says, "this ignorance, which thinks

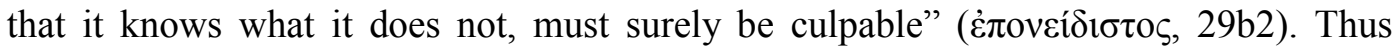
whenever Socrates discovers a pretender who "does not possess excellence but says he does" (29e5-30a1), Socrates finds him worthy of "blame" (ỏveı 1 ஸ̃, 30a1) and makes it his goal to make the other aware of the ignorance and so to convert him to the life of a philosopher.

How can the philosopher, at the middle level, be free of guilt (neither good nor bad) and the non-philosopher, at the lowest level, be guilty (bad), when both are alike ignorant of how to live well as human beings? Rudebusch (2009: 23-24), using homicide as an example, distinguishes the relevant levels of guilt. The highest two levels of guilt accrue to voluntary wrongdoing: premeditated murder and murder committed on the spur of the moment, as a crime of passion. While these two levels are established legal distinctions, Socrates denies that they have any moral application to human beings, since "no one willingly does wrong" (Gorgias 509e). Rudebusch defends Socrates' denial on the authority of the oracle: we all lack the expertise to judge even whether to live or die is a harm or benefit. Indeed Socrates finds "culpable" those who think they know that death is something bad, in the passage quoted above (29b). Yet there remains a distinction between two kinds of involuntary wrongdoing, between for example homicide as a result of negligence or recklessness, which of course is culpable, and accidental homicide, which is guilt free. As Rudebusch (2009: 26) points out, it is reckless negligence that Socrates accuses Meletus of, "saying Meletus is unrighteous because he 'treats serious matters frivolously' (24c5-6)." Meletus, as we might say, is playing with fire or going off half-cocked. Indeed, as Rudebusch (2009: 27) says, anytime Socrates finds a pretender to knowledge - that is, a non-philosopher - he imputes guilt to him. Socrates "will blame him for scorning the things that are of most importance and caring more for what is of less worth" (30a1-2).

That the unrighteousness of such scorn and misguided care is involuntary does not free the pretender from guilt $[\ldots]$ Socrates' accusers do not intend to act unrighteously. Yet Socrates warns that they ought to beware, because "the real difficulty is to escape the condition of being wicked, which is quicker than death [...] My accusers, who are clever and quick, have been overtaken by the faster, by wickedness 
[...] they will go away convicted by truth herself of depravity and unrighteousness" (39a7-b6). Simply not intending to act unrighteously is not enough, then. Rather, one must in addition do everything in one's power to ensure that one does not act unrighteously, so that even if one unwittingly is responsible for harm to oneself or others, one will not be culpable because every precaution has been taken.

To explain the guilt Socrates has in mind, Rudebusch gives an analogy. The non-philosopher, undertaking all sorts of actions as a human being, bears the same type of guilt as a gunner shooting blindly or carelessly.

The decision to raise a child, to make friends with another person, or to go to college any of these choices might lead to disaster for oneself or others. Like such activities of human life, the use of firearms might lead to serious harm. Because of the risks, everyone will agree that if I don't know how to use firearms, it is better for me not to use them at all than to play with them ignorantly (2009: 22).

The philosopher by contrast, lives a guilt free life. By actively striving to find out how to act as virtuously as possible and not presuming falsely to already have figured this out, the philosopher avoids being recklessly negligent and any harm done to himself or others is nothing more than an unfortunate accident for which no one is to blame.

Like the Fruitlessness interpretation in either its Bitter or Think for Yourself version, the Philosophical Interpretation sees as Socrates' goal in the Laches to demonstrate to Laches and Nicias their ignorance. But the point of the demonstration is neither to show them their bitter fruitlessness nor to stimulate them to think for themselves. It is to lead them to a guilt free life. Rudebusch (2009: 28) gives the following reason to show that Socrates valued such a guilt-free life:

Socrates says that he is free of guilt, even unintentional guilt, and knows that his guiltfree condition is an even rarer achievement than that of an Olympic champion. This is why he proposes that the city provide him free meals in the Prytaneum, an honor reserved for champions and heroes, on the grounds that he "never intentionally wronged anyone" (37a5), an achievement that he also describes as "never wronging any one" $(37 b 2-3)$.

If Socrates aims to free us of the guilt of living an unexamined life and recklessly endangering ourselves and others, we can explain the structure of the Laches and take away this moral: we must either reckon with our ignorance or risk ruining ourselves, our loved ones, and community. 


\section{Conclusion}

While we no longer have Socrates around to goad us from out of our slumber, we are fortunate to still possess the Socratic dialogues authored by Plato. We began by posing the problematic situation for interpreting these dialogues and the wealth of conflicting views as to how one should read them. Our assessment of the alternatives leads us to endorse the Philosophical Interpretation. Alone among the alternatives, it does not impose a hidden, extraneous, or ideological significance upon the dialogue, nor violate the letter of the text in order to explain to us its spirit and meaning.

Socrates intends to demonstrate that his partners in conversation are mere pretenders to knowledge and seeks to convert them to a life spent in search of wisdom, a life that is free of guilt, unlike that of non-philosophers. It is only through such a life that we escape the unwitting guilt characteristic of the life we lead before such conversion, that of not knowing that we do not know and yet acting as though we do, a form of hubris that in Plato's presentation of the Socratic mission provokes not divine nemesis but rather an all-too-human poetic justice, a case of being undone by our own 'blind spot', as Nicias is undone by his over-reverence in Sicily and Laches at Mantinea by his inability to distinguish the wisdom that should accompany courage as anything other than prudential calculation, which latter he cannot accept since it eliminates the risks of the unknown that are a condition for displaying courage in the first place. Laches then, must obstinately ensure that he runs risks where he need not, in order to be courageous, and in practice this amounts to ceding to his own strategic advantage to his enemy and engendering thereby his own defeat. He would rather be a more courageous fool than a less courageous sound-minded victor in spite of his admission in the dialogue that courage, being a fine thing, cannot be foolish. Each of us, too, Plato's Socrates would suggest, has just such a blind spot so long as we persist in the belief that we know more than that we are ignorant. Unless we, too, confront the depth of our ignorance we are just as much in danger as the two generals.

George Rudebusch (Northern Arizona University)

Chris Turner (DePaul University) 


\section{Bibliography}

Benson, H. (ed.) 1992. Essays on the Philosophy of Socrates. Oxford.

Bonitz, H. 1858. Platonische Studien. ${ }^{1}$ Berlin. -1886. Platonische Studien. ${ }^{3}$ Berlin.

Brickhouse, T. C., and Smith, N. D. 1997. "Socrates and the Unity of the Virtues". Journal of Ethics 1: 311-23.

2010. Socratic Moral Psychology. Cambridge.

Cappelletti, A. J. 1994. "Laques: la dialectica del coraje". Revista de filosofia de la Universidad de Costa Rica 32: 71-80.

Chappell, T. 2004. Reading Plato's Theaetetus. Indianapolis.

Cohen, H. 1878. "Platons Ideenlehre und die Mathematik". Reprinted in Schriften zur Philosophie und Zeitgeschichte ed. by A. Görland and E. Cassirer, vol. 1, Berlin, 1928 (336-366).

Devereux, D. 1977. "Courage and Wisdom in Plato's Laches”. Journal of the History of Philosophy 15: 129-141. DOI: 10.1353/hph.2008.0611

1992. "The Unity of the Virtues in Plato's Protagoras and Laches". The Philosophical Review 101: 765-789. DOI: 10.2307/2185924

-2006. "The Unity of the Virtues". A Companion to Plato. Ed. H Benson. Oxford: $325-40$.

Dobbs, D. 1986. "For Lack of Wisdom: Courage and Inquiry in Plato's Laches". Journal of Politics 48: 825-850. DOI: http://dx.doi.org/10.2307/2131002

Emlyn-Jones, C. 1999. "Dramatic Structure and Cultural Context in Plato's Laches". Classical Quarterly 49: 123-138. DOI: http://dx.doi.org/10.1093/cq/49.1.123

Erler, M. 1987. Der Sinn der Aporien in den Dialogen Platons. Berlin.

Ferejohn, M. 1982. "The Unity of Virtue and the Objects of Socratic Inquiry". Journal of the History of Philosophy 20:1-21. DOI: 10.1353/hph.1982.0014

1983-4. "Socratic Virtue as the Parts of Itself". Philosophy and Phenomenological Research 44 3: 377-88.

Foley, R. 2009. “The Better Part of Valor: The Role of Wisdom in Plato's Laches". History of Philosophy Quarterly 26: 213-233.

Foucault, M. 2011. The Courage of Truth: The Government of Self and Others II. Lectures at the Collège de France, 1983-1984. New York. DOI: 10.5860/choice.49-1983

Friedländer, P. 1928. Platon, vol. 1 Page references to $3^{\text {rd }}$ edition, Berlin, 1964. 1930. Platon, vol. 2. Page references to $3^{\text {rd }}$ edition, Berlin, 1964.

Fröhlich, B. 2007. Die sokratische Frage: Platons Laches. Berlin.

Gaiser, K. 1959. Protreptik und Paränese bei Platon. Untersuchungen zur Form des platonischen Dialogs, Stuttgart.

1961. "Das Platon-Bild Stenzels und seine wissenschaftliche Bedeutung”. In Stenzel 1961. 
1963. Platons ungeschriebene Lehre. Stuttgart, $1^{\text {st }}$ edition.

1998. Platons ungeschriebene Lehre. Stuttgart, $3^{\text {rd }}$ edition.

Gonzalez, F. J. 1998. Dialectic and Dialogue: Plato's Practice of Philosophical Inquiry. Evanston. DOI: 10.5860/CHOICE.37-1474

Grote, G. 1865. Plato and the other companions of Sokrates, vol. 1. Page references to $2^{\text {nd }}$ edition, London,1885. DOI: http://dx.doi.org/10.1017/CBO9780511710117

Hadot, P. 1995. Philosophy as a Way of Life: Spiritual Exercises from Socrates to Foucault. Malden. 2002. What is Ancient Philosophy? Cambridge, MA.

Hardy, J. 2011. Jenseits der Täuschungen-Selbsterkenntnis und Selbstbestimmung mit Sokrates. Göttingen.

Hegel, G. W. F. 1848. Vorlesungen über die philosophie der Geschichte, $3^{\text {rd }}$ edition. Berlin.

Hiestand, M. 1923. Das sokratische Nichtwissen in Platons ersten Dialogen, Zürich.

Hildebrandt, K. 1933. Platon: Der Kampf des Geistes um die Macht, Berlin.

Hobbs, A. 2006. Plato and the Hero: Courage, Manliness and the Impersonal Good. Cambridge. DOI: $10.1017 / \mathrm{cbo} 9780511551437$

Hoerber, R. 1968. "Plato's Laches”. Classical Philology 63: 95-105. DOI: 10.1086/365344

Irwin, T. 1995. Plato's Ethics. New York. DOI: 10.1093/0195086457.001.0001

Jaeger, W. 1928. "Die platonische Philosophie als Paideia". In Das Platonbild: Zehn Beitrage zum Platonverstandnis, ed. K. Gaiser. Hildesheim, 1969.

-1936. Paideia: Die Formung des griechischen Menschen, vol. 2, Berlin.

Jahn, E. 1864. Platon's Laches. Vienna.

Kahn, C. H. 1998. Plato and the Socratic Dialogue: The Philosophical Use of a Literary Form. Cambridge. DOI: http://dx.doi.org/10.1017/CBO9780511585579.014

Kohak, E. 1960. “The Road to Wisdom”. Classical Journal 56: 123-132.

Krämer, H. J. 1959. Arete bei Platon und Aristoteles. Zum Wesen und zur Geschichte der platonischen Ontologie, Heidelberg.

-1972. "Über den Zusammenhang von Prinzipienlehre und Dialektik bei Platon". In Das Problem der ungeschrienbenen Lehre Platons, ed. J. Wippern, Darmstadt.

Lamb, W. R. M. 1955. Plato, vol. 8. Cambridge, MA.

Manuwald, B. 2000. "Die Schlussaporie in Platons Laches". Rheinisches Museum für Philologie, Neue Folge 143: 179-191.

Meister, R. 1921. "Thema und Ergebnis des Platonischen Laches". Wiener Studien 42: 103-114.

Natorp, P. 1903. Platos Ideenlehre: Eine Einführung in den Idealismus. Leipzig.

1921. Platos Ideenlehre: Eine Einführung in den Idealismus, $2^{\text {nd }}$ edition. Leipzig. 
Nehamas, A. 1975. "Confusing Universals and Particulars in Plato's Early Dialogues". Review of Metaphysics 29: 287-306.

O'Brien, M. 1971. "The Unity of the Laches". Essays in Ancient Greek Philosophy. Ed. by J. P. Anton and G. L. Kustas. Albany, 303-315.

Penner, T. 1973. "The Unity of Virtue". Philosophical Review 82: 35-68. Reprinted in Benson 1992. DOI: $10.2307 / 2184238$

1992a. "What Laches and Nicias Miss - and Whether Socrates Thinks Courage is Merely a Part of Virtue". Ancient Philosophy 12: 1-27. DOI: 10.5840/ancientphil199212142 ------1992b. "Socrates and the Early Dialogues". The Cambridge Companion to Plato. Ed. R. Kraut. Cambridge. DOI: 10.1017/ccol0521430186.004

Pohlenz, M. 1913. Aus Platos Werdezeit: Philologische Untersuchungen. Berlin.

Reshotko, N. 2006. Socratic Virtue. Making the Best of the Neither-Good-nor-Bad. Cambridge. DOI: $10.1017 /$ cbo9780511482601

Roochnik, D. 1996. Of Art and Wisdom: Plato's Understanding of Techne. University Park.

Santas, G. 1964. "The Socratic Paradoxes". Philosophical Review 73:147-64. Revised version in Santas 1979. DOI: $10.2307 / 2183333$

---------1971. "Socrates At Work On Virtue And Knowledge In Plato's Laches". The Philosophy of Socrates. Ed. G. Vlastos. Garden City, 177-208. 1979. Socrates: Philosophy in Plato's Early Dialogues. London.

Schleiermacher, F. 1839. Geschichte der Philosophie. Berlin.

Schmid, W. 1992. On Manly Courage: a Study of Plato's Laches. Carbondale.

Steinhart. K. 1850. Platon's saemmtliche Werke, vol. 1. Leipzig.

Stenzel, J. 1927. "Wissenschaft und Staatsgesinnung bei Platon”. Kiel. 1928. Platon der Erzieher, Leipzig. 1961. Platon der Erzieher, Hamburg.

Stokes, M. 1986. Plato's Socratic Conversations: Drama and Dialectic in Three Dialogues. Baltimore.

Strauss, L. 1978. The City and Man. Chicago: University of Chicago Press.

Susemihl, F. 1855. Die genetische Entwickelung der Platonischen Philosophie Part 1, Leipzig.

Szlezák, T. A. 1985. Platon und die Schriftlichkeit der Philosophie. Berlin. DOI: 10.1515/9783110848762

Taylor, C. C. W. 2000. Socrates: A Very Short Introduction. Oxford.

Tessitore, A. 1994. "Courage and Comedy in Plato's Laches". The Journal of Politics 56: 115-133. DOI: $10.2307 / 2132348$

Turner, F. M. 1984. The Greek Heritage in Victorian Britain. New Haven.

Umphrey, S. 1976. "Plato's Laches on Courage". Apeiron: A Journal for Ancient Philosophy and Science 10: 14-22. DOI: 10.1515/apeiron.1976.10.2.14 
Vlastos, G. 1954. "The Third Man Argument in the Parmenides". Philosophical Review 63: 319-49.

1972. "The Unity of Virtues in the Protagoras". Review of Metaphysics 25: 415-458. Reprinted in Vlastos 1981.

-1981. Platonic Studies, $2^{\text {nd }}$ edition. Princeton.

Von Arnim, H. 1914. Platos Jugenddialoge und die Entstehungszeit des Phaidros. Leipzig.

Wieland, W. 1982. Platon und die Formen des Wissens, $2^{\text {nd }}$ edition. Göttingen. 1999. Platon und die Formen des Wissens, $3^{\text {rd }}$ edition. Göttingen.

Woodruff, P. 1976. "Socrates on the Parts of Virtue". Canadian Journal of Philosophy 2 (Supplementary): 101-116.

Zeller, E. 1859. Die Philosophie der Griechen volume II part 1, $2^{\text {nd }}$ edition. Tübingen. 1875. Die Philosophie der Griechen volume II part 1, $3^{\text {rd }}$ edition. Leipzig. 